NBER WORKING PAPER SERIES

\title{
THE ECONOMICS OF WORKAHOLISM: WE SHOULD NOT HAVE WORKED ON THIS PAPER
}

\author{
Daniel S. Hamermesh \\ Joel Slemrod \\ Working Paper 11566 \\ http://www.nber.org/papers/w11566 \\ NATIONAL BUREAU OF ECONOMIC RESEARCH \\ 1050 Massachusetts Avenue \\ Cambridge, MA 02138 \\ August 2005
}

Hamermesh: Edward Everett Hale Centennial Professor of Economics, University of Texas at Austin, and research associate, NBER and IZA; Slemrod: Paul W. McCracken Collegiate Professor of Business Economics and Public Policy, University of Michigan, and research associate, NBER. We thank Bruno Frey, Don Fullerton, Steven Haider, Peter Katuscak, Wojtek Kopczuk, George Loewenstein, Hugo Mialon, Sue Mialon, Dan Silverman, Kazimierz Stanczak, Stephen Trejo and participants at seminars at several universities for helpful comments. We are especially indebted to Haider for providing the RHS extract and to Julia Power for providing the PSID extract used in Section III. The views expressed herein are those of the author(s) and do not necessarily reflect the views of the National Bureau of Economic Research.

(O2005 by Daniel S. Hamermesh and Joel Slemrod. All rights reserved. Short sections of text, not to exceed two paragraphs, may be quoted without explicit permission provided that full credit, including $\odot$ notice, is given to the source. 
The Economics of Workaholism: We Should Not Have Worked on This Paper

Daniel S. Hamermesh and Joel Slemrod

NBER Working Paper No. 11566

August 2005

JEL No. J22, H24, D91

\section{$\underline{\text { ABSTRACT }}$}

A large literature examines the addictive properties of such behaviors as smoking, drinking alcohol and eating. We argue that for some people addictive behavior may apply to a much more central aspect of economic life: working. Workaholism is subject to the same concerns about the individual as other addictions, is more likely to be a problem of higher-income individuals, and can, under conditions of jointness in the workplace or the household, generate negative spillovers onto individuals around the workaholic. Using the Retirement History Survey and the Panel Study of Income Dynamics, we find evidence that is consistent with the idea that high-income, highly educated people suffer from workaholism with regard to retiring, in that they are more likely to postpone earlier plans for retirement. The evidence and theory suggest that the negative effects of workaholism can be addressed with a more progressive income tax system than would be appropriate in the absence of this behavior.

Daniel S. Hamermesh

Department of Economics

University of Texas

Austin, TX 78712-1173

and NBER

hamermes@eco.uetxas.edu

Joel B. Slemrod

Office of Tax Policy Research

University of Michigan Business School

701 Tappan Street, Room A2120D

Ann Arbor, MI 48109-1234

and NBER

jslemrod@umich.edu 


\section{Introduction-the Nature of Workaholism}

Economists have recently re-considered whether a range of individual behaviors are selfdestructive, and possibly addictive, and have proposed that it may be Pareto-superior to tax them in order to induce people to abandon or cut back on them. Prominent examples include O'Donoghue and Rabin (2002) and Gruber and Köszegi (2004), who have calculated the appropriate tax on cigarettes that would "internalize" the costs that smokers impose on themselves. The focus of this "new paternalism," associated with the burgeoning field of behavioral economics, has been on a set of activities (smoking, drinking, overeating, and gambling, in particular) whose demand is income inelastic and on public policy responses in the form of "sin taxes" that are highly regressive.

Here we begin to explore the economic implications of a self-destructive behavior that is likely to be more prevalent among affluent people-workaholism. The term has become deeply entrenched in common parlance since Oates (1971) introduced it. It appears roughly 50,000 times in a search of the Internet, and the term "workaholic" appears an additional 670,000 times. ${ }^{1}$ One dictionary (Merriam-Webster) defines a workaholic as "a compulsive worker." A psychologist noted recently:

Workaholism is an addiction. It's the illusion, and associated destructive behaviors caused from that illusion, that a person can effectively address challenges in life and work exclusively by working harder at work.

The addiction seems to follow this cycle. Discomforts in life and work cause the person to seek relief from those discomforts. The primary form of relief that the person (the "workaholic") has access to, and believes in the most, is to feel good by accomplishing something as part of their job at work. So the workaholic attends to getting something done at work. However, as the workaholic attends increasingly to getting things done at work, their personal life begins to suffer from lack of attention. As their personal life suffers, it causes more discomfort for the workaholic, so the workaholic works even harder at getting more things done at work, causing their personal lives to suffer even more -- and the vicious cycle, or compulsive work syndrome, goes on and on. (McNamara, 2004)

\footnotetext{
${ }^{1}$ Search made using Google, July 11, 2005.
} 
The emphasis appears to be on addiction and on the negative implications for the person's life away from the workplace. Workaholism, or work addiction, has not yet been accepted into the official psychological or psychiatric nomenclature, and there is no consensus characterization of its underlying nature. Killinger (1991, p. 7) asserts that the "peak performances [of work addicted people] are a form of ecstasy, and the accompanying surge of adrenaline acts like a drug." Fassel (1990, p. 3) speculates that workaholism may be a unique addiction in that "it has both a substance component (addiction to adrenaline) and a process component (addiction to the actual process of working)."

While measuring the amount of smoking or drinking is easy, measuring the extent of addictive or even harmful smoking, drinking and overeating is more problematic. Even the neurological effects of alcohol consumption, an addictive substance that really has just one active ingredient, are far from fully understood (Fromme and D'Amico, 1999). Similarly, while it is fairly straightforward to measure hours worked, determining what fraction of those hours represents excessive, compulsive, or addictive work is not easy. Going to a more basic level and trying to determine the biological effects, if any, of addictive work has not even been attempted.

The most informative direct evidence comes from a Canadian study of self-reported workaholism. In the Canadian General Social Survey, 30 percent of adults said that they are workaholics (Kemeny, 2002). High-income people were much more likely to state that they are workaholics: 38 percent of those with incomes over $\$ 100,000$ admitted to being a workaholic, compared to only 23 percent of people with incomes below $\$ 10,000$ (and 22 percent of those with no income!). Of those who work 60 or more hours per week, 53 percent self-reported workaholism, while only 17 percent self-reported this among adults who worked fewer than 20 hours per week. While there is clearly some base level of subjective feelings of workaholism in a population, self-reported workaholism is strongly related to hours worked per week and to income. 
A variety of health problems, ranging from exhaustion to high blood pressure, have been attributed to workaholism (Spence and Robins, 1992). Statistics Canada's 1996-97 National Population Health Survey linked longer work hours (but not workaholism per se) with increased chances of weight gain, smoking or alcohol consumption. High stress can lead to high blood pressure, which is a risk factor for heart disease. In addition, stress takes a toll on the immune system, making stressed-out workaholics more vulnerable to other illnesses. In Japan death from overwork has its own name-karoshi. In 1994, the Japanese Economic Planning Agency estimated the annual number of karoshi deaths at about 1,000, or five percent of all deaths from cardiovascular and cerebrovascular disease among people ages 25-59. Other estimates have put the number as high as 10,000 workers per year (Nishiyama and Johnson, 1997).

In a number of countries feelings of being stressed for time are more strongly positively related to the amount of time people spend at the workplace than to any other cause (Hamermesh and Lee, 2003). Clearly, working long hours causes people to complain a lot about work that they view as excessive; but they continue to work hard, so that we must assume that those whom others might view as workaholics are as well off as they might possibly be given their current opportunities and preferences.

Psychologists also maintain that there are negative spillover effects of workaholic behavior. According to Robinson (1998b), both spouses and children may be adversely impacted: "Children are affected by parental work addiction in ways that are mentally unhealthy and can cause problems well into young adulthood." Robinson et al (2001) found that those who were married to workaholics had higher divorce rates, greater rates of marital estrangement, fewer positive feelings about their marriage, and felt less in control of their lives and marriages.

We have found only three uses of the term "workaholism" in the published economics literature. Mitchell and Fields (1984) and Kahn and Lang (1991) briefly use the term to describe an inherent preference for work, something clearly different from the notion of addiction in the 
economics or other literatures. Benabou and Tirole (2004) use the term similarly, but do so in the context of a model of endogenous preferences.

Two questions about workaholism seem relevant for positive economics. First, what are the dynamic effects on one's own future utility? Second, how might a person's long hours of work affect his or her co-workers or family? In Section II we explore these questions by developing models that try to identify conditions under which a person's long hours might or might not be detrimental to his or her own and others' welfare.

Can we reasonably call a person's long work hours an addiction; or do long work hours just show that someone has an exogenous relative lack of distaste for work? This is an extremely difficult question to answer. We deal with it obliquely in Section III by presenting some empirical analyses of work effort late in life and focusing on whether departures from prior expectations about hours of work are systematically related to characteristics - income and education - that generated long hours earlier in the work life.

In Section IV we discuss some normative aspects of workaholism and draw out its implications for optimal tax progressivity. We show that if workaholism provides a reason for government to override individuals' expressed tradeoffs between consumption and work, it will tend to increase the optimal degree of progressivity as long as the negative aspects of workaholism are associated with income-earning ability.

\section{Workaholism and Its Effects}

We define workaholism as an addiction to work that is acquired as a consequence of working early in a career, and that manifests itself as an increase in one's subsequent labor supply. It is distinct from an inherent characteristic of the worker, some extra taste for work that leads a worker to supply unusually many hours of labor to the market over an entire career. Rather, it is best thought of as a hysteresis effect that develops some time after the worker has entered the labor force and finds, as a consequence of work already performed, that the disutility from additional work has become less than he/she envisioned at the start of the career. The 
addiction may or may not be rational, i.e., foreseen by the worker. We first briefly consider cases in which intervention may be justified solely on account of the workaholic, then discuss in detail considerations when the development of workaholism spills over onto people in close proximity to the workaholic.

If the individual ignores the impact of working in the first period on the utility function in the second period (i.e., is "myopic"), then he or she will oversupply labor in that period relative to what would maximize the true utility function. This issue does not arise if we are dealing with rational workaholics, in the sense of Becker and Murphy (1988), who recognize that working in the first period builds up the stock of the addictive good that has a positive marginal utility in the second period. $^{2}$ When individuals are rational in this way, absent externalities there is no a priori case for government intervention in the market for addictive goods and services.

This conclusion has been challenged by, inter alia, O'Donoghue and Rabin (2002) and Gruber and Köszegi (2004), who embed the Becker-Murphy framework in a multi-period model in which consumers have time-inconsistent preferences with quasi-hyperbolic discounting. At any point in time, people discount utility in the future more heavily than utility in the current period, but apply a lower discount rate to consumption across future periods. When the next period arrives, they again apply the higher discount factor to future utility, leading to time inconsistency. ${ }^{3}$ In this formulation the rational addict may be naïve-unaware of the time inconsistency problem — or sophisticated - aware of the problem, but unable to exercise selfcontrol when the next period arrives; unlike the naïve person, the sophisticate may make choices today to minimize the costs of the anticipated future self-control problem Except in the case of a rational addict with exponential preferences and the ability to exercise self-control, there is an argument for government intervention in the addict's choices. For example, in the case of

\footnotetext{
${ }^{2}$ In a two-period model the distinction between the stock of past working and last period's work is not meaningful, although it is in a multi-period model.

${ }^{3}$ Loewenstein et al (2003) allude to deeper reasons why this may occur.
} 
cigarettes investigated by O'Donoghue and Rabin (2002) and Gruber and Köszegi (2004), excise taxes can improve utility by essentially facing the consumer with a price that more accurately reflects the appropriately discounted future health costs of smoking.

The same reasoning applies to workaholism. We argue that, for some people, current work increases the desire for future work (known as "reinforcement") and lowers the utility from a given amount of working ("tolerance"). If workaholics either do not recognize these effects, or do recognize them but have time-inconsistent preferences and imperfect self-control, then government intervention arguably can increase their utility as measured consistently. We argue, furthermore, that workaholism differs from, for example, addiction to cigarettes in two important ways. First, its incidence is likely to be highest among highly compensated, highly educated individuals, so that the appropriate corrective tax scheme will be highly progressive, in sharp contrast to the highly regressive burden of corrective cigarette excise taxes. Second, workaholism is likely to involve significant spillovers to co-workers and spouses that amplify its effects. We turn next to the spillover issues, and return in Section IV to the implications for the optimal progressivity of the tax system.

\section{B. Spillovers in the Workplace}

We do not wish to argue that all workaholics are irrationally myopic and/or that they are characterized by time-inconsistent, possibly hyperbolic, preferences. Although it seems highly unlikely to us, it may be that many are completely rational, forward-looking, have the appropriate inter-temporal preferences and can exercise self-control. Even if so, as long as their co-workers and family members (spouse and children) forecast their behavior imperfectly, their workaholism might have negative effects on the people around them that are worth examining.

To address the conditions required for the spillover effects of workaholism to be important, we first allow each generation to consist of two equally productive workers, $W$ and $O$, who either work, supplying 1 unit of labor in a period, or do not work, supplying 0 units of labor (enjoying 1 unit of leisure, $L$ ). Assume for simplicity that their production is described by: 


$$
Q_{t}=\min \left\{1-L_{t}^{W}, 1-L_{t}^{O}\right\}{ }^{4}
$$

We assume that during Period 1 each worker has a reservation wage of $R_{1}=0$, so that each supplies 1 unit of effort, producing 1 unit of output that is shared according to some bargain. This assumption allows us to abstract from any issues of labor supply in the first period, and reflects the fact that those who do work choose to do so early in their adult lives. The surpluses for the two workers are $w_{1}{ }^{W}-R_{1}=w_{1}{ }^{W}$, and $w_{1}{ }^{O}-R_{1}=w_{1}{ }^{O}$, with $Q_{1}=1=w_{1}{ }^{W}+w_{1}{ }^{O}$. Cooperative Nash bargaining yields an equal split of the output and a wage $w_{l}{ }^{W}=w_{l}{ }^{O}=.5$ received by each worker.

At first both workers anticipate having a reservation wage of $R_{2} \geq .5$ during Period 2, so that both expect ex ante to retire. Between Periods 1 and 2, however, Worker W announces that, as a consequence of his working in Period 1, work now yields such little disutility that his reservation wage has remained at zero. Worker $\mathrm{W}$ has become addicted to work and is now a workaholic. $^{5}$ He thus wishes to continue to supply 1 unit of labor in Period 2. Given the technology, however, he cannot do this productively by himself-he needs the cooperation of Worker $O$, who prefers to spend Period 2 retired. Worker $O$ requires a wage greater than $R_{2}^{O}$ to be induced to remain in the labor force and to continue working with Worker $W$.

The Nash bargain over the unit output in Period 2 now becomes:

$$
\max w_{2}{ }^{W}\left[w_{2}{ }^{O}-R_{2}{ }^{O}\right] \text { subject to } w_{2}{ }^{W}+w_{2}{ }^{O}=1 .
$$

The bargain in (2) yields $w_{2}{ }^{W} \leq .25, w_{2}{ }^{O} \geq .75$, with $\mathrm{w}_{2}{ }^{\mathrm{W}}$ decreasing from .25 , and $w_{2}{ }^{O}$ increasing from .75, as $R_{2}{ }^{O}$ rises above .5. In order to indulge his newfound taste for work in Period 2, the workaholic must share the surplus generated by work (which is larger than anticipated because the alternative of leisure is no longer as attractive) equally with the complementary, non-

\footnotetext{
${ }^{4}$ So long as workers are q-complements in production, so that an increase in the input of one raises the marginal product of the other, the general implications of this Part are unchanged.

${ }^{5}$ This example features both reinforcement and tolerance, because in Period 2 the workaholic has a lowerthan-anticipated relative valuation of leisure (i.e., a higher relative valuation of working) and a lower-thananticipated total utility for any given basket of wages and leisure, if utility is taken as $w+R$.
} 
workaholic worker. With his lower (0 in our example) reservation wage, this means that he must accept no more than one-quarter of the output of the two-person "firm" as wages in order to satisfy his desire to continue working. The workaholic has chosen, rationally or not, to alter his behavior from what the other worker expected. His choice, however, makes his co-worker better off, because he must do so in order to improve his own situation. More generally, in a world in which the workaholic must contract with equally powerful and complementary co-workers to indulge his addiction, he must share with them a sufficient part of the rents he derives from the addiction. Merely developing a decreased relative distaste for market work is not enough to generate spillovers on one's co-workers.

In this model the workaholic's changed preferences must be unexpected by the other worker. Otherwise he/she would have contracted initially for a different path of effort/leisure over the two periods. The main point, however, is that even with the assumption of the development of workaholism and imperfect foresight, the workaholism benefits the non-workaholic co-worker.

We have assumed thus far that the non-workaholic has no ties to the workaholic and has to be offered a welfare-improving bribe not to retire. Consider an expanded two-period model, in which labor supply varies along a continuum from 0 to 1 , there is no necessary retirement in Period 2, and many workers make up two-person firms in each period. Assume the production function in Period 1 is unchanged as in expression (1). The first-period utility functions of workers i are:

$$
U_{l}^{i}=w_{l}^{i}+.5\left[L_{l}^{i}\right]^{5}, \mathrm{i}=W, O .
$$

Each utility-maximizing worker will supply .75 units of labor during Period 1, obtaining a wage of .375 , leisure of .25 and utility of .625 during that period after the cooperative Nash bargain is struck. $^{6}$

The parties' interactions in Period 1 generate firm-specific improvements that raise second-period production if they stay together, so that:

\footnotetext{
${ }^{6}$ After substituting in (3) for the $w_{l}{ }^{i}$ the Nash term becomes $\left\{.5\left[1-L_{l}{ }^{W}\right]+.5\left[L_{l}{ }^{W}\right]^{.5}\right\}\left\{.5\left[1-L_{l}{ }^{\mathrm{O}}\right]+.5\left[L_{l}{ }^{O}\right]^{.5}\right\}$.
} 


$$
Q_{2}=A \cdot \min \left\{1-L_{2}{ }^{W}, 1-L_{2}{ }^{O}\right\} \text {, where } A>1.25 \text {. }
$$

Assume that at the end of Period 1 Worker $W$, but not Worker $O$, becomes a workaholic. We represent his changed attitudes by assuming that he gets no pleasure from leisure, so that his Period 2 utility becomes $U_{2}{ }^{w}=w_{2}{ }^{w}$. The workaholic would like to set $\mathrm{L}_{2}{ }^{\mathrm{W}}=0$, exactly as in the previous case.

We introduce one crucial new element into the model: that the workaholic controls the firm and sets $O$ 's hours of work in the firm at the same value, 1 (so that $L_{2}{ }^{O}=0$ ), which the workaholic desires for himself. Worker $O$ has two choices: 1) Leave the firm and partner with a new, non-workaholic (and otherwise identical) fellow worker, foregoing the match-specific productivity improvements indicated by A and obtaining $U_{2}{ }^{O}=.625$, the same utility he obtained in Period 1; 2) Stay with his newly workaholic co-worker/boss, who needs to pay him at least .625 (and thus yielding utility of at least .625 as well) to induce him to stay in the firm and also work all the time. Since with $L_{2}{ }^{W}=L_{2}{ }^{O}=0, Q_{2}>1.25$, Worker $W$ can afford to do this and retain Worker $O$ 's services. Worker $O$ is better off making the second choice and staying in the relationship. His utility, however, is lower than it would have been had Worker $W$ not become a workaholic and the partnership had instead both reaped the fruits of its specific investment. In that case, under Nash bargaining in Period 2 each party would have chosen to work $1-.25 / A^{2}$, obtaining a wage of $.5 \mathrm{~A}-.125 / A$ and enjoying leisure of $.25 / A^{2}$, and utility $U_{2}^{i}=.5 A+.125 / A>$ .625 .

If for any reason the non-workaholic is or becomes subordinate, in the sense that the workaholic can unilaterally decide how much to work; and if their labor is complementary, the non-workaholic can be induced to work more, at a wage greater than .625 , rather than take a wage of .375 with the same amount of leisure as before but at another firm. Staying with the workaholic is a better alternative for the non-workaholic than breaking up the firm; but it yields 
him lower utility than his investment in the relationship in Period 1 would have made possible in Period 2.

The specifics of this example are unimportant. The essential point is that the workaholic boss has surprised the co-worker, made him worse off than if the boss had not become a workaholic and than the co-worker expected when he entered the relationship, but better off than at any alternative job. The essential features that generate the negative effect on the co-worker are the jointness and specificity in production, and the workaholic's ability to determine his own and the non-workaholic's hours of work.

\section{Spillovers in the Household}

To examine further the conditions under which workaholism can have spillover effects on non-workaholics, consider now a married couple's labor-leisure choices. We show, in an example in which consumption of leisure and goods are joint, that the non-workaholic spouse is worse off even if she can choose her leisure hours freely. What are crucial to the model are jointness and specificity in consumption, and the workaholic's ability to determine his hours of work unilaterally.

Assume that the couple gets married at the start of Period 1 of their two-period lives. We assume that all consumption goods are public in the household (thus ignoring issues of their distribution in order to concentrate on the spouses' labor supply) and that there is no bequest motive. Each spouse has one (continuous) unit of time to allocate during each period. We assume that each spouse $i$ 's utility function while married during period $\mathrm{t}$ is:

$$
U^{i}\left(L_{t}^{i}, \min \left\{L_{t}^{M}, L_{t}^{F}\right\}, C_{t}\right), i=M, F,
$$

and, crucially, that $U_{2}^{i}>0$ - both spouses enjoy leisure time together (or in a broader context, enjoy combining their time and goods jointly). Substantial evidence, e.g., Fong and Zhang (2001) and Hamermesh (2002), suggests that this is the case.

Based on their (exogenous) market wage rates, their preferences and the alternative utilities $\mathrm{V}^{\mathrm{i}}$ available outside the marriage, they strike a marital bargain that yields a jointly 
lifetime utility-maximizing sequence of pairs of leisure demands, $L_{t}^{M^{*}}$ and $L_{t}^{F^{*}}$, where (*) denotes the couple's maximum. We assume that this sequence implies that both spouses plan to be retired during the second period, so that $L_{2}{ }^{M^{*}}=L_{2}{ }^{F^{*}}=1$, possibly because of the decline in their wage rates.

Spouse $M$ becomes addicted to his work during Period 1 and announces at the start of Period 2 that he is reneging on the initial bargain and unilaterally setting $1>L_{2}^{M^{*}} \geq 0$, i.e., he is not going to retire. Thus Spouse $F$ is faced with the alternatives of quitting the marriageaccepting the (unchanged) $V^{F}$-or re-striking the bargain given the new amount of leisure that Spouse $M$ chose for himself.

Assume that there is some $L_{2}^{F^{*}}$ such that she is better off staying in the marriage than getting divorced. Will this $L_{2}{ }^{F^{*}}$ still equal the planned $L_{2}{ }^{F^{*}}=1$ ? Spouse $F$ now chooses $L_{2}{ }^{F}$ to maximize:

$$
U^{F}\left(L_{2}{ }^{F}, \min \left\{L_{2}^{M^{*}}, L_{2}^{F}\right\}, C_{2}\right)-V^{F},
$$

with $C_{2}=S+w_{M}\left[1-L_{2}^{M^{*}}\right]+w_{F}\left[1-L_{2}^{F}\right]$, and $S$ being the couple's pre-retirement savings. Spouse $M$ 's increased supply of labor benefits Spouse $F$ because she shares the extra consumption that his unplanned earnings in Period 2 generate, so that her surplus may increase too. $^{7}$ If, however, the partial derivative $U_{2}^{F}$ is sufficiently large relative to $U_{1}^{F}$ and $U_{3}^{F}$ at the pair $\left(L_{2}{ }^{M^{*}}<1, L_{2}{ }^{F^{*}}=1\right)$, her surplus will be reduced by Spouse $M$ 's workaholism. This will occur when the negative effect on her excess utility (over her threat point) of her husband's decreased leisure more than offsets the extra household consumption that the couple can attain because of his additional earnings.

In this case although the non-workaholic spouse's utility is increased by the extra goods consumption in which she shares, the reduction in utility arising from the loss of joint, shared leisure exceeds this gain. If this condition holds, she will choose to reduce her leisure in order to

\footnotetext{
${ }^{7}$ In a more realistic case, with bargaining also over assignable consumption goods, there is substantial evidence that Spouse M's greater labor supply will give him an increased share of the additional purchases that his earnings finance (see, e.g., Lundberg et al, 2003 and Lee, 2004).
} 
restore her optimum, albeit at a lower level of well-being than if Spouse $M$ had not developed workaholism, obtaining still more (decreasingly-valued) consumption goods in order to avoid spending (valuable) time alone. Despite this, she is still better off than if she had chosen to quit the marriage.

We are not claiming that the development of workaholic characteristics always hurts the non-workaholic spouse. Clearly the non-workaholic spouse gains some goods consumption; but in cases where the complementarity of spouses' leisure is sufficiently strong s/he can be made worse off than if the spouse had not become a workaholic. This loss either leads her to leave the marriage or to reduce the amount of leisure enjoyed below what she had planned. Household bargaining and the caring nature of marriage can lead to the appearance that workaholism is contagious - one spouse will increase her/his labor supply in response to the other's workaholic behavior. The reasons are similar to those discussed at the end of Part B-complementarity and prior investment in relational capital.

Here and in Part B the altered welfare (of those involved with the workaholic) occurs only because the workaholic's work effort is unexpected by his/her potential co-workers and family members and because the workaholism arises among those who are powerful enough to determine their own hours unilaterally rather than bargain them with co-workers or spouses. We do observe that more educated workers and those who earn more per hour work longer hours per week in the United States. ${ }^{8}$ But unexpectedly long hours among more educated, higher-paid

\footnotetext{
${ }^{8}$ Among the nearly 740,000 workers in the Outgoing Rotation Groups of the Current Population Survey (CPS) from 1998 through 2002, weekly work hours average 39.2 among those with a high-school diploma, but 43.1 among those with more than a college degree. Alternatively, and perhaps more relevant, only 9.1 percent of high-school graduates worked 50 hours per week or more, while 28.9 percent of those with postgraduate degrees did. Despite the negative bias induced when we define hourly earnings as weekly earnings divided by weekly hours, we still find that hours average only 38.1 (with 9.3 percent working 50+ hours) among workers in the bottom half of the distribution of hourly earnings, while they average 41.8 (with 18.9 percent working 50+ hours) among those in the top half, and 42.3 (with 24.7 percent working $50+$ hours) among those in the top decile of hourly earnings.
} 
workers have spillover effects only because those are typically the workers who can control the work environment and who in a marriage have more power. ${ }^{9}$

\section{Some Empirical Hints of Workaholism}

It is extremely difficult to provide conclusive evidence of any kind of addiction. The data needed to specify the second-order difference equations in quantities that are implicit in Becker and Murphy (1988) are rarely available to study rational addiction to any activity. While a few longitudinal data sets have sufficient information on hours worked to provide information on this endogenous variable, typically one cannot identify the kind of exogenous shock (such as changes in excise tax rates in the study of tobacco addiction, as in Gruber and Köszegi, 2004) that would allow one to discern the presence of addiction, rational or otherwise.

Because the data for a convincing formal test for workaholism are simply not available, in this Section we perform several indirect tests that suggest that people's expectations about their subsequent work behavior are systematically unfulfilled in ways that imply the prior development

of workaholism. ${ }^{10}$ In each case we examine whether, conditional upon their expressed plans to reduce the supply of labor to the market, individuals differ systematically in their subsequent labor supply. The general model is:

$$
H_{t+k}=\gamma \bullet{ }_{t} H^{e}{ }_{t+k}+\beta_{1} \mathrm{X}_{\mathrm{t}}+\beta_{2} Z_{t}+\varepsilon_{t},
$$

\footnotetext{
${ }^{9}$ In the 1998-2002 CPS data managers averaged 43.2 hours per week, with 25.5 percent working at least 50 hours weekly; among other respondents, weekly hours averaged 38.9 , with only 10.8 percent working $50+$ hours. Holding age, education and weekly earnings constant, managers worked 2 hours more per week on average than other respondents.

${ }^{10} \mathrm{We}$ initially examined workaholism using a framework similar to that used to examine addiction to tobacco and other addictions (see, e.g., Becker et al, 1994, on tobacco and Olekalns and Bardsley, 1996, on coffee). Specifying a second-order difference equation in hours of market work as functions of current, past and future earnings, and estimating the equations over the American National Longitudinal Survey of Youth 1979 and the German Socioeconomic Panel, we did find consistent significant impacts of future work hours on current hours of market work, and some evidence that future earnings also mattered. We abandoned this approach in favor of the more suggestive, albeit non-formal methods discussed here because of our unwillingness to claim that anything in those equations could reasonably be viewed as exogenous to the agents' decisions and because of the absence of convincing instruments for those endogenous variables.
} 
where $H_{t+k}$ denotes some measure of labor supply at time $t+k,{ }_{t} H^{e}{ }_{t+k}$ is the expressed expectation at time $t$ of labor supply at time $t+k, X$ is one or several variables that might be correlated with workaholism, $Z$ are controls, and the $\gamma$ and $\beta$ are parameters to be estimated.

We argue that positive impacts of the variables in $X$ on hours of work at $t+k$, conditional on expectations at time $t$ about work hours at $t+k$, indicate that workers with those identifiable characteristics may be workaholics. People with characteristics measured by $X$ may state that they expect to work a certain number of hours in the future (be they positive hours, or zero hours and thus retirement). Positive estimated values of $\beta_{1}$ would indicate, however, that, when the future arrives, they in fact work systematically more than they predicted. Within the vector $X$ we focus on measures of educational attainment and personal income at time $t$, both because we believe that higher-income, more-highly-educated individuals tend to have more control over their work environment and because the workaholism literature suggests that the jobs held by these individuals are more likely to generate addictive behavior. Both sets of estimates reported here deal with retirement behavior-comparing how the relationship between actual retirement and expectations about future labor supply is modified by differences in characteristics at the time the expectations were expressed. ${ }^{11}$

The first empirical examination is based on the Retirement History Survey (RHS), a sixwave biennial panel that began in 1969 with a group of over 10,000 people ages 58-63. In each of the first three waves employed respondents were asked about their plans to retire, with the possible responses being either an expected age, "never" or "don't know." In each wave respondents were also asked to state whether they were fully retired, partly retired or not retired.

We estimate ordered probits describing the three possible retirement states for each of Waves 2-4 of the RHS, with 2 being fully retired, 1 being partly retired, 0 being not retired. We include as measures of ${ }_{t} H^{e}{ }_{t+k}$ all the expressed plans for the age of retirement that had been

\footnotetext{
${ }^{11}$ In the vernacular of addiction, retirement is akin to going "cold turkey" on working.
} 
recorded before time $t+k .^{12}$ Thus the first pair of ordered probits describes retirement status in 1971 as a function of planned age of retirement expressed in 1969, the second describes 1973 retirement status by plans in 1969 and 1971, etc. The vector $X$ alternately includes educational attainment (measured in 1969) and personal income in $1969 .^{13}$

One difficulty in estimating a version of (4) over the samples from the RHS is that large fractions (typically around 35 percent) of respondents who expressed retirement plans answered "never." In measuring ${ }_{t} H_{t+k}^{e}$ we treat "never" as equal to the highest retirement age recorded among those who gave an expected retirement age. Unreported estimates using only those respondents who gave a specific age yield results quite similar to those listed in Table 1. Also reported in the table are the estimated impacts of measures of the direction of changes, if any, in the individual's (self-reported) health status. In each wave the respondent was asked whether his/her health was better, worse or equal to that of others the same age. The vector $Z$ includes measures of age and marital status.

The results of estimating the ordered probits for retirement status in Wave 2 are reported in the first two columns of Table 1. As also shown by Haider and Stephens (2004) using these data, retirement plans predict behavior quite well—ceteris paribus, those with higher expected retirement ages in 1969 are less likely to be retired in 1971. Conditional on those plans, however, our results demonstrate that individuals with more education are less likely to follow through with their expressed plans for retirement. Similarly, those with higher personal income in 1969 (while working, and thus mostly in the form of higher earnings) are also less likely to be retired in 1971 than otherwise identical workers with the same expressed plans for retirement. Each additional year of schooling reduces the likelihood of being fully or partly retired by about as much as one-

\footnotetext{
${ }^{12}$ We also estimated ordered probits for Waves 3 and 4 in which only retirement plans expressed in 1969 were included. The results on the crucial measures of educational attainment and 1969 personal income did not differ qualitatively from those presented in Table 1 .

${ }^{13}$ When both of these measures are included in the same ordered probit, each of the two estimated parameters is significantly positive.
} 
third of a year's increase in the planned age of retirement. Thus, for example, someone who planned to retire at 65 would be no less likely to be retired at a given age than someone with three fewer years of schooling who had planned to retire at 66 .

The results for retirement status in Wave 3 (1973) and Wave 4 (1975) look very similar to those describing retirement status in Wave 2. In each case, individuals with more education, or those with greater personal income in 1969 , are less likely to be retired conditional on the plans for retirement that they expressed in previous biennial interviews. While in each of these later waves the most recent retirement expectations significantly affect retirement status, retirement expectations expressed earlier have significant impacts on actual retirement as well. By inference the measures of retirement expectations are noisy indicators of actual plans, so that each provides some independent expression of how the respondent expects to behave.

The estimated impacts of improvements in self-assessed health are generally insignificant. However, declines in self-assessed health, conditional on retirement expectations in the previous wave, are strongly positively correlated with the likelihood of being retired (or moving to partial retirement). Whether this effect is causal, or whether respondents who have cut back on their market work are simply using health as a rationalization, cannot be determined. It is worth noting, however, that the crucial coefficient estimates - those on education and Wave 1 income - change only very slightly if the health measures are excluded from the equations.

The main result from the RHS data is that measures that might indicate an addiction to work have some power in predicting retirement beyond that of recent expressed plans for retirement. The estimates suggest that more educated and higher-income respondents simply cannot help themselves: They express an expectation of retirement, but when the time comes they are less likely to be retired. Note that if it were fashionable among more educated or higherpaid workers to pooh-pooh the notion of retirement, we would then find that, conditional on expressed retirement expectations, they would be more likely to be retired, not less likely. The 
results for the RHS seem consistent with workaholic behavior but not with some kind of conformity to group norms.

The RHS results are interesting but suffer from the difficulty that the time interval $(k)$ between the expression of retirement plans and their possible realization is quite short - six years at most. It is difficult to believe that the more educated people in this sample have developed an addiction to work this late in their working lives. Rather, the evidence is better interpreted as suggesting that they may have become workaholics earlier in their careers and that, analogous to substance addicts, they could not admit their addiction and maintained they would retire (go cold turkey) when in fact they were unable to do so. While the evidence is thus consistent with one aspect of addictive behavior (to work), it is possible that there is something else that makes more educated or higher-earning people more likely to remain in the labor force despite their plans to retire. This potential difficulty might be avoided were the time interval $k$ longer. ${ }^{14}$

In its 1976 wave the Panel Study of Income Dynamics (PSID) asked labor market participants, "If you were to get enough money to live as comfortably as you would like for the rest of your life, would you continue to work?" We interpret the answer to this question as revealing information about the respondent's taste for market work. In our analyses of these data we combine "No" and "Don't know" (the latter containing a tiny fraction of respondents) into one group, thus converting the responses into the binary indicator "Would not work." We study retirement behavior observed in 2001, including all individuals still in the PSID in that year who were working in 1976 and thus answered the "Would you work?" question in 1976.

The sample is restricted to respondents age 55 or over in 2001 (and thus age 30 or over in 1976), so there is a non-trivial chance that the respondent is retired in 2001, defined as working fewer than 500 hours per year for pay. In the probits describing the probability of retirement we are inquiring whether, conditional on expressed commitment in 1976 to market work, actual

\footnotetext{
${ }^{14}$ To be sure, a longer interval makes it more likely that relevant information is revealed during that period. If that information is correlated with the $\mathrm{X}$ vector, it will affect our interpretation of the estimated coefficients as evidence of the presence of workaholism.
} 
retirement status is affected by hours of work in 1976 and educational attainment in 1976. The probit specifications are thus similar to those estimated on the RHS sample, but they have the advantage of a much longer interval between observing the subjective expression of the marginal disutility of work and the behavioral outcome.

The odd-numbered columns of Table 2 present means of the crucial variables. Nearly 29 percent of male workers and 42 percent of female workers age 30 and over in 1976 claimed that they would not continue working if their financial status allowed it. The men averaged 45 hours of market work per week in 1976, the women 28 hours per week. In 2001, 55 percent of males (whose average age was 67) were retired by our definition, while 70 percent of women (average age 69) were retired. $^{15}$

The probit derivatives are reported in the even-numbered columns of Table 2. Also included in the probits are indicators of marital and health status in 2001, and years of age in 2001. Subjective beliefs indicating a respondent's attachment to market work in 1976 significantly reduce the probability of being retired after age 55, 25 years later. Even accounting for this possibly fixed indicator of the relative distaste for market work, among both men and women those who worked more in 1976 were significantly less likely to be retired in 2001 . Either the expression of commitment to market work failed to capture fully people's relative lack of distaste for market work; or, consistent with the notion of workaholism, those who worked more in 1976 continued to build up an addiction to market work that led them to be less likely to be retired in 2001 conditional on the preferences that they expressed in $1976 .{ }^{16}$ Using the same specification for men as in Table 2, but restricting the sample to married men, the results differ little. Those estimates are also essentially unaffected if we include the wife's hours of work in

\footnotetext{
${ }^{15}$ The women are older both because of their lower mortality rates and because the question was addressed in 1976 only to workers, thus excluding the many young mothers who were non-participants in the labor force.

${ }^{16}$ If instead of using an indicator of retirement status we estimate a tobit specification on hours of work in 2001 , the results are essentially the same.
} 
2001, suggesting, consistent with the discussion in Section IIC, that the possible complementarity of spousal leisure does not affect the extent to which the husband develops workaholic behavior.

The results are not due to differences in earnings capacity. Analogous to the estimates from the RHS, conditional on preferences for work and on annual hours in 1976, more educated respondents were less likely to be retired in 2001. Here too, those individuals whose earnings capacity might have led them to build up a stock of "market work capital" find it more difficult to leave market work in their later years. ${ }^{17}$ The results thus mirror exactly the creation of an addiction and its expression in subsequent behavior.

One might be concerned that the returns to schooling rose between 1976 and 2001, so that all we are observing is a positive labor-supply response to an unanticipated increase in wage rates among the better educated. However, this alternative explanation is not consistent with one key pattern in the data. Among full-time male workers in the CPS Outgoing Rotation Groups between 1979 and 2001 the 95/5 wage differential grew by 32.6 log points, while among full-time female workers the same differential grew by $43.8 \log$ points. The fairly solid evidence that women's labor-supply elasticities exceed men's (e.g., Ashenfelter and Layard, 1986), combined with more rapidly rising earnings inequality among women over this period, should in the absence of workaholism have led to larger negative effects of differences in education on retirement probabilities, conditional on the subjective response in 1976, among women than among men. That the negative effects are nearly twice as large among men is inconsistent with a labor supply argument. It is consistent with workaholic behavior, since the subjective evidence cited earlier and Burke (1999) suggest the addiction is at least as prevalent among men.

The findings are also almost certainly not due to the development of an increasing bequest motive that, rather than workaholic behavior, spurs those working longer hours in 1976 to

\footnotetext{
${ }^{17}$ The cognitive aspects of the question about future willingness to work may bias the estimated impact of education toward zero. If respondents interpret the question in terms of their expectations, and if, as seems likely, more highly educated respondents expect to earn more, their likelihood of responding "Would not work" is overestimated, imparting a positive bias to the education variable in the probits.
} 
be less likely to be retired in 2001, all else equal. Re-estimating the probits on the quite small sample of people who were unmarried in both 1976 and 2001, and who are thus much less likely than others to have a strong bequest motive, we find that the conditional estimated impact of hours worked in 1976 on retirement status in 2001 is as large as in the full sample.

In two data sets we have found evidence that, conditional on expectations about retirement or on expressed tastes for market work, exogenous factors that might be correlated with their having previously become addicted or that might lead individuals to become addicted to market work affect actual retirement behavior. The results show that unusually large amounts of prior market work and higher potential earnings ability (arising from greater educational attainment) lead people who express beliefs that they will cut back on their work to be unwilling to do so. While not proof of the existence of workaholic behavior, both sets of results are consistent with behavior that indicates addiction to market work.

\section{Policy Implications of Workaholism}

In either the case of work addiction of naïve, myopic individuals who do not take into account the future negative consequences of their own behavior, or in the case of rational (forward-looking) work addiction with time inconsistency and self-control problems, one could argue that the government's policy objective should depend on something other than the objective functions that govern individuals' decisions. In the myopia case, arguably the government ought to consider the long-term impact of decisions that individuals fail to consider. In the case of forward-looking individuals with self-control problems, the government should consider that its policies could serve as a substitute for the individuals' self-control. Such policies have been referred to as optimal corrections for "internalities," in contrast to the classic Pigouvian correction for externalities. Depending on the nature of the workaholic's interactions with co-workers and family members, workaholism may raise issues of externalities as well as internalities.

It is worth working through how the presence of internalities and externalities due to workaholism affects optimal tax policy, in the way that has been done for cigarette addiction 
without consideration of the distributional implications of the optimal excise tax. Addressing distributional issues is particularly important in the context of workaholism, because it affects the principal source of income for most people and because the evidence suggests that work addiction is primarily an affliction of high-income, highly-educated people.

To illustrate how workaholism would affect the optimal extent of tax progressivity, we draw on a model proposed by Kanbur et al (2004), who provide a general non-welfarist formulation of the now-classic approach to optimal tax policy formulated by Mirrlees (1971). In this model, which has no explicit dynamic element, the government chooses a general, non-linear tax schedule based on income. There is a continuum of individuals, each with an identical utility function, where $U=U(C, H)$ is defined over consumption $C$ and hours worked $H$, but differing in their income-earning ability, or the wage rate, $w$. There is a distribution of $w$ on the interval $(\underline{w}, \bar{w})$ represented by the density function $f(w)$. Gross income equals $w H(\equiv z)$ and $T(w H)$ is the non-linear tax schedule set by the government, so that individuals choose $C$ and $H$ to maximize $U(C, H)$ subject to $C=w H-T(w H)$.

The government chooses $T(w H)$ subject to a revenue constraint, and individuals' optimization decisions to maximize:

$$
S=\int_{\underline{w}}^{\bar{w}} P(C, H, w) f(w) d w,
$$

where $P=P(C, H, w)$ following Seade (1980) is "the social utility" derived from a $w$-individual's consumption and labor. $P(C, H, w)$ may be related to, but is not in general identical to, the utility function that individuals seek to maximize, which is $U($.$) .$

In this setting, Kanbur et al (2004) show that the optimal marginal tax rate $\left(T^{\prime}\right)$ at a given income level is characterized by

$$
T^{\prime}(z(w))=\left(P_{C}\left(s-s^{p}\right)\right) / \lambda w-\mu(w) U_{C} S_{w} / \lambda f,
$$


where $s$ is the individual's marginal rate of substitution of $H$ in terms of $C$ as indicated by the $U($. function (defined to be a positive number), $s^{p}=-\left(P_{H} / P_{C}\right)$ denotes the social, or paternalist, marginal rate of substitution, and $s-s^{p}$ reflects the internality or externality created by workaholism. ${ }^{18}$ The terms $\lambda$ and $\mu(w)$ are the multipliers for the budget constraint and incentive compatibility constraint, respectively; $\mathrm{f}$ is the density of $w$. The second term of the expression is familiar from Mirrlees (1971), and represents the second-best motive for marginal distortion, arising from the fact that ability is not observable by the government, which forces it to tax on the basis of observable, but not immutable, income. If there is no divergenece between $s$ and $s^{p}$-no internality or externality — then the standard result obtains.

The first term on the right-hand side of (6) captures the divergence between social and private preferences, and optimally induces individual choices to correspond to social preferences. This correction could be paternalistically motivated, as in the case of workaholism arising from time-inconsistent individuals being unable to overcome their own self-control problems. It could also arise from the desire to address the externalities arising from workaholism, as discussed here. In the presence of either factor, the social marginal rate of substitution of labor in terms of consumption will be lower than what individuals act on, that is, $s^{p}<s$, so the first term in (6) implies that an additional positive marginal tax is added to the otherwise optimal tax schedule as a disincentive to labor supply. Moreover, if workaholism is more prevalent among high-ability people, as we suspect it is based in part on the empirical evidence presented here, then $s-s^{p}$ is increasing in $w$, and the optimal income tax system not only features higher marginal tax rates than otherwise, but also marginal tax rates that rise with income more rapidly than otherwise. This is in sharp contrast to the policy prescriptiion in the literature on cigarette taxes, which calls for very high excise taxes on an income-inelastic commodity.

\footnotetext{
${ }^{18} \mathrm{We}$ assume that $s_{w}$, the partial derivative of the individual's marginal rate of substitution with respect to $w$, is less than zero. This is the agent monotonicity assumption that ensures that both consumption and gross earnings increase with the wage rate. Note also that the private and social marginal rate of substitution are defined slightly differently here than in Kanbur et al (2004).
} 
We note that a separate literature argues that individuals work "too hard" because they systematically mispredict their future utility, although the mechanism is not addiction per se. For example, Frey and Stutzer (2004) argue that individuals overestimate the future utility that they will receive from goods that satisfy extrinsic needs-including income and fame-relative to the future utility they will receive from goods satisfying intrinsic needs, including feeling connected to others or having control over one's future. This failure may arise because individuals adapt more quickly to goods with extrinsic attributes, or because extrinsic needs are easer to quantify and compare, making it easier for individuals to rationalize the consumption of a good with extrinsic attributes (Hsee et. al., 2003). ${ }^{19}$ Applied to an individual's retirement decision, this argument suggests that individuals will overestimate their utility from future labor income and underestimate the utility from spending time with friends or relaxing in other ways. The result is the same as if work is addictive-individuals choose to work too much, imposing costs on themselves. ${ }^{20}$

\section{Conclusions}

A large literature examines the addictive properties of such behaviors as smoking, drinking, eating, and gambling. In this study we argue that addictive behavior may apply to a much more central aspect of economic life: working. In contrast to most of the traditionally studied kinds of addictive behaviors, working is more likely to involve interpersonal externalities and may be more likely to be a characteristic of high-income individuals. Using two quite different data sets, we find evidence that is consistent with the idea that high-income, highly educated people are particularly likely to suffer from workaholism with regard to the retirement decision - going cold turkey on their addictive behavior; they are less likely than other workers to

\footnotetext{
${ }^{19}$ There is ample evidence that as income increases, so too does one's perception of how much income is needed to just get by (Easterlin 2001, Stutzer 2004).

${ }^{20}$ Frey and Stutzer (2004) discuss mandatory maximum working hours as a corrective policy. Unlike the United States many European countries impose maximum hours on firms that are covered by legislation regulating overtime hours.
} 
adhere to their earlier expressed beliefs about their eventual retirement. This evidence suggests that corrective policy might involve a more progressive tax burden than otherwise, and we derive the optimal income tax structure in the presence of the internalities and externalities that might result from workaholism.

Implicit throughout this study has been the assumption that workaholism occurs because of the reinforcement and tolerance that an individual develops to his/her work or career. An alternative cause may instead be that people develop apparent workaholic behavior because they develop addictions to the consumer goods whose increased purchase is made possible by the fruits of their market work. ${ }^{21} \mathrm{~A}$ useful project would attempt to distinguish the behavioral implications of workaholic behavior that arises through an addiction to consumption from the kind of workaholism discussed here.

More generally, the research agenda regarding workaholism should attempt to clarify the circumstances under which work is addictive, and document its behavioral implications, including the commitment devices that people who lack self-control might seek out. More precise information about the health costs of workaholism to the worker and the external costs to co-workers and family members is essential to quantify the appropriate corrective policies. If our sense that workaholism is an important aspect of labor market behavior can be corroborated by future research, then our sub-titular claim will be proven wrong. We hope so.

\footnotetext{
${ }^{21}$ Models of habit formation in consumption have been developed in macroeconomics since Abel (1990) and Constantinides (1990), although supporting microeconomic evidence has been elusive, as evidenced by Dynan (2000). More recently, models such as Gurgdiev (2004) have distinguished habitual dependence in leisure demand. Neither stream of the macroeconomics literature has stressed the normative implications of habit formation.
} 


\section{REFERENCES}

Abel, Andrew B. 1990. "Asset Prices under Habit Formation and Catching Up with the Joneses." American Economic Association, Papers and Proceedings, 80 (May): 38-42.

Ashenfelter, Orley, and Richard Layard. 1986. Handbook of Labor Economics, Volume 1. Amsterdam: North-Holland.

Becker, Gary, and Kevin Murphy. 1988. "A Theory of Rational Addiction.” Journal of Political Economy, 96 (Aug.): 675-99.

Becker, Gary, Michael Grossman and Kevin Murphy. 1994. "An Empirical Analysis of Cigarette Addiction.” American Economic Review, 84 (June): 396-418.

Benabou, Roland, and Jean Tirole. 2004. "Willpower and Personal Rules." Journal of Political Economy, 112 (Aug.): 848-886.

Burke, Ronald. 1999. "Workaholism in Organizations: Gender Differences." Sex Roles, 41 (Sept.): 333-45.

Constantinides, George M. 1990. "Habit Formation: A Resolution of the Equity Premium Puzzle." Journal of Political Economy, 98 (June): 519-543.

Dynan, Karen. 2000. "Habit Formation in Consumer Preferences: Evidence from Panel Data." American Economic Review, 90 (June): 391-406.

Easterlin, Richard. 2002. "Income and Happiness: Toward a Unified Theory." Economic Journal, 111 (July): 465-84.

Fassel, Diane. 1990. Working Ourselves to Death: The High Cost of Workaholism and the Rewards of Recovery. New York: Harper Collins.

Fields, Gary, and Olivia Mitchell. 1984. "The Economics of Retirement Behavior.” Journal of Labor Economics, 2 (Jan.): 84-105.

Fong, Yuk-fai and Junsen Zhang. 2001. "The Identification of Unobservable Independent and Spousal Leisure.” Journal of Political Economy, 109 (Feb.): 191-202.

Frey, Bruno and Alois Stutzer. 2004. "Does the Political Process Mitigate or Accentuate Individual Biases Due to Mispredicting Future Utility?" Paper presented at "Behavioral Public Finance: Toward a New Agenda" conference, Ann Arbor, MI.

Fromme, Kim, and Elizabeth D'Amico. 1999. "Neurobiological Bases of Alcohol's Psychological Effects." In K. Leonard and H. Blane (eds.), Psychological Theories of Drinking and Alcoholism. New York: Guilford Press.

Gruber, Jonathan and Botond Köszegi. 2004. "Tax Incidence When Individuals Are Time Inconsistent: The Case of Cigarette Excise Taxes." Journal of Public Economics, 88 (Aug.): 1959-87. 
Gurdgiev, Constantin. 2004. "A Life-Cycle Model of Habitual Dependence in Leisure Demand.” Unpublished manuscript, Trinity College, Dublin, Ireland.

Haider, Steven and Melvin Stephens. 2004. "Is There a Retirement-Consumption Puzzle? Evidence Using Subjective Retirement Expectations.” NBER Working Paper No. 10257, January.

Hamermesh, Daniel. 2002. "Timing, Togetherness and Time Windfalls." Journal of Population Economics, 15 (Nov.): 601-23.

Hamermesh, Daniel and Jungmin Lee. 2003. "Stressed Out on Four Continents: Time Crunch or Yuppie Kvetch.” National Bureau of Economic Research, Working Paper No. 10186, December.

Hsee, Christopher H., Jiao Zhang, Fang Yu, and Yiheng H. Xi. 2003. "Lay Rationalism and Inconsistency between Predicted Experience and Decisions." Journal of Behavioral Decision Making, 16 (Oct.): 257-72.

Kahn, Shulamit, and Kevin Lang. 1991. "The Effect of Hours Constraints on Labor Supply Estimates." Review of Economics and Statistics, 73 (Nov.): 605-611.

Kanbur, Ravi, Jukka Pirttila, and Matti Tuomola. 2004. "Non-Welfarist Optimal Taxation and Behavioral Public Economics." Mimeo, University of Tampere, Finland, August 25.

Kemeny, Anna. 2002. "Driven to Excel: A Portrait of Canada's Workaholics." Canadian Social Trends (Spring). Statistics Canada, Catalogue No. 11-008.

Killinger, Barbara. 1991. Workaholics: The Respectable Addicts. Toronto: Key Porter Books.

Lee, Jungmin. 2004. “Observable and Unobservable Household Sharing Rules: Evidence from Young Couples' Pocket Money.” IZA Discussion Paper No. 1250, August.

Loewenstein, George, Ted O'Donoghue and Matthew Rabin. 2003. "Projection Bias in Predicting Future Utility." Quarterly Journal of Economics, 118 (Dec.): 1209-48.

Lundberg, Shelly, Richard Startz and Steven Stillman. 2003. "The Retirement-Consumption Puzzle: A Marital Bargaining Approach.” Journal of Public Economics, 87 (May): 11991218.

McNamara, Carter. 2004. "Workaholism," http://www.mapnp.org/library/prsn_wll/wrkholic.htm 8/15/04.

Mirrlees, James. 1971. "An Exploration in the Theory of Optimal Income Taxation." Review of Economic Studies, 38 (April): 175-208.

Nishiyama, Katsuo and Jeffrey Johnson. 1997. "Karoshi-Death from Overwork: Occupational Health Consequences of Japanese Production Management." International Journal of Health Services 27(4): 625-41.

Oates, Wayne. 1971. Confessions of a Workaholic. New York: World Press. 
Olekalns, Nilss and Peter Bardsley. 1996. "Rational Addiction to Caffeine: An Analysis of Coffee Consumption.” Journal of Political Economy, 104 (Oct.): 1100-04.

Robinson, Bryan.E. 1998a. Chained to the Desk: A Guidebook for Workaholics, Their Partners and Children, and the Clinicians Who Treat Them. New York: New York University Press.

------. 1998b. "The Workaholic Family: A Clinical Perspective." American Journal of Family Therapy, 26 (Jan.-March): 65-76.

Robinson, Bryan, Jane Carroll and Claudia Flowers. 2001. "Marital Estrangement, Positive Affect, and Locus of Control Among Spouses of Workaholics and Spouses of Nonworkaholics: A National Study." American Journal of Family Therapy, 29 (Oct.): 397-410.

Scott, Kimberly, Keirsten Moore, and Marcia Miceli. 1997. "An Exploration of the Meaning and Consequences of Workaholism." Human Relations 50 (March): 287-314.

Seade, Jesus. 1980. "Optimal Non-Linear Policies for Utilitarian Motives." In D. Collard, R. Lecomber and M. Slater (eds.), Income Distribution: The Limits to Redistribution. Bristol: Scientechnica.

Spence, Janet, and Ann Robbins. 1992. "Workaholism: Definition, Measurement, and Preliminary Results.” Journal of Personality Assessment, 58 (Feb.): 160-78.

Statistics Canada. 1999. "Long Working Hours and Health.” The Daily. November 16.

Stutzer, Alois. 2004. "The Role of Income Aspirations in Individual Happiness." Journal of Economic Behavior and Organization, 54 (May): 89-109. 
Table 1. Ordered Probit Estimates and Descriptive Statistics, Retirement History Survey Waves 2-4 (1971, 1973, 1975): Dependent Variable is Fully, Partly or Not Retired*

\begin{tabular}{|c|c|c|c|c|c|c|}
\hline \multirow[b]{2}{*}{$\mathrm{R}^{\mathrm{e}}$ Wave 1} & \multicolumn{2}{|c|}{ Wave 2} & \multicolumn{2}{|c|}{ Wave 3} & \multicolumn{2}{|c|}{ Wave 4} \\
\hline & $\begin{array}{l}-.0700 \\
(.0041)\end{array}$ & $\begin{array}{l}-.0703 \\
(.0041)\end{array}$ & $\begin{array}{l}-.0534 \\
(.0048)\end{array}$ & $\begin{array}{l}-.0540 \\
(.0048)\end{array}$ & $\begin{array}{l}-.0294 \\
(.0064)\end{array}$ & $\begin{array}{c}-.0310 \\
(.0064)\end{array}$ \\
\hline $\mathrm{R}^{\mathrm{e}}$ Wave 2 & & & $\begin{array}{l}-.0492 \\
(.0048)\end{array}$ & $\begin{array}{l}-.0495 \\
(.0048)\end{array}$ & $\begin{array}{l}-.0184 \\
(.0073)\end{array}$ & $\begin{array}{c}-.0190 \\
(.0073)\end{array}$ \\
\hline $\mathrm{R}^{\mathrm{e}}$ Wave 3 & & & & & $\begin{array}{l}-.0750 \\
(.0077)\end{array}$ & $\begin{array}{r}-.0747 \\
(.0076)\end{array}$ \\
\hline Years of Education & $\begin{array}{l}-.0273 \\
(.0058)\end{array}$ & & $\begin{array}{l}-.0357 \\
(.0064)\end{array}$ & & $\begin{array}{l}-.0376 \\
(.0083)\end{array}$ & \\
\hline $\begin{array}{l}\text { Wave } 1 \text { Income } \\
(\$ 000)\end{array}$ & & $\begin{array}{l}-.0120 \\
(.0028)\end{array}$ & & $\begin{array}{l}-.0068 \\
(.0019)\end{array}$ & & $\begin{array}{l}-.0153 \\
(.0033)\end{array}$ \\
\hline Health Improved & $\begin{array}{l}-.0308 \\
(.0588)\end{array}$ & $\begin{array}{l}-.0266 \\
(.0588)\end{array}$ & $\begin{array}{l}.0206 \\
(.0642)\end{array}$ & $\begin{array}{l}.0316 \\
(.0639)\end{array}$ & $\begin{array}{l}-.0080 \\
(.0768)\end{array}$ & $\begin{array}{l}-.0096 \\
(.0765)\end{array}$ \\
\hline Health Worsened & $\begin{array}{l}.1977 \\
(.0493)\end{array}$ & $\begin{array}{l}.2117 \\
(.0489)\end{array}$ & $\begin{array}{l}.3439 \\
(.0559)\end{array}$ & $\begin{array}{l}.3602 \\
(.0558)\end{array}$ & $\begin{array}{l}.2099 \\
(.0849)\end{array}$ & $\begin{array}{c}.2343 \\
(.0847)\end{array}$ \\
\hline Pseudo- $\mathrm{R}^{2}$ & .1165 & .1153 & .1142 & .1103 & .0875 & .0880 \\
\hline $\mathrm{N}=$ & 4683 & 4705 & 2991 & 3002 & 1507 & 1512 \\
\hline $\begin{array}{l}\text { Wave } 1 \text { Income } \\
(\$ 000)\end{array}$ & $\begin{array}{c}11.356 \\
(10.012)\end{array}$ & & Means: & & & \\
\hline Education & $\begin{array}{l}10.05 \\
(3.57)\end{array}$ & & & & & \\
\hline $\mathrm{R}^{\mathrm{e}}$ Wave 1 & $\begin{array}{l}68.34 \\
(5.39)\end{array}$ & & $\begin{array}{l}69.49 \\
(5.31)\end{array}$ & & $\begin{array}{l}69.42 \\
(5.30)\end{array}$ & \\
\hline $\mathrm{R}^{\mathrm{e}}$ Wave 2 & & & $\begin{array}{l}70.65 \\
(5.08)\end{array}$ & & $\begin{array}{l}70.50 \\
(5.09)\end{array}$ & \\
\hline $\mathrm{R}^{\mathrm{e}}$ Wave 3 & & & & & $\begin{array}{l}70.12 \\
(4.82)\end{array}$ & \\
\hline Age & $\begin{array}{l}62.16 \\
(1.68)\end{array}$ & & $\begin{array}{l}63.76 \\
(1.62)\end{array}$ & & $\begin{array}{l}65.67 \\
(1.57)\end{array}$ & \\
\hline
\end{tabular}

*The ordered probits also include measures of age and marital status. Standard errors of the parameter estimates are in parentheses below them here and in Table 2. 
Table 2. Estimates of Retirement Probability (Annual Hours< 500): Probit Derivatives and Descriptive Statistics, PSID 2001*

\begin{tabular}{|c|c|c|c|c|c|c|}
\hline & \multicolumn{2}{|c|}{ All } & \multicolumn{2}{|c|}{ Men } & \multicolumn{2}{|c|}{ Women } \\
\hline & Mean & Derivative & Mean & Derivative & Mean & Derivative \\
\hline Would not work & $\begin{array}{r}0.349 \\
(.477)\end{array}$ & $\begin{array}{l}.0918 \\
(.0306)\end{array}$ & $\begin{array}{l}0.293 \\
(0.456)\end{array}$ & $\begin{array}{l}.1188 \\
(.0461)\end{array}$ & $\begin{array}{l}0.420 \\
(0.494)\end{array}$ & $\begin{array}{l}.0549 \\
(.0373)\end{array}$ \\
\hline $\begin{array}{l}\text { Annual Hours } 1976 \\
(000)\end{array}$ & $\begin{array}{l}1.886 \\
(0.817)\end{array}$ & $\begin{array}{l}-.0688 \\
(.0217)\end{array}$ & $\begin{array}{l}2.267 \\
(0.665)\end{array}$ & $\begin{array}{l}-.0851 \\
(.0345)\end{array}$ & $\begin{array}{c}1.408 \\
(0.748)\end{array}$ & $\begin{array}{l}-.0429 \\
(.0073)\end{array}$ \\
\hline Years of Education & $\begin{array}{l}12.49 \\
(3.08)\end{array}$ & $\begin{array}{l}-.0218 \\
(.0055)\end{array}$ & $\begin{array}{l}12.58 \\
(3.28)\end{array}$ & $\begin{array}{l}-.0280 \\
(.0076)\end{array}$ & $\begin{array}{l}12.37 \\
(2.81)\end{array}$ & $\begin{array}{l}-.0134 \\
(.0076)\end{array}$ \\
\hline Pseudo- $\mathrm{R}^{2}$ & & .3314 & & .3322 & & .3065 \\
\hline Retired & $\begin{array}{l}0.616 \\
(0.487)\end{array}$ & & $\begin{array}{c}0.547 \\
(0.498)\end{array}$ & & $\begin{array}{c}0.702 \\
(0.458)\end{array}$ & \\
\hline$N=$ & & 311 & & 30 & & 581 \\
\hline
\end{tabular}

